Cornell Law Library

Scholarship@Cornell Law: A Digital Repository

Cornell Law Faculty Publications

Faculty Scholarship

2011

\title{
The Origins, Nature, and Promise of Empirical Legal Studies and a Response to Concerns
}

Theodore Eisenberg

Cornell Law School, ted-eisenberg@lawschool.cornell.edu

Follow this and additional works at: http://scholarship.law.cornell.edu/facpub

Part of the Law and Economics Commons, Law and Society Commons, and the Legal History, Theory and Process Commons

\section{Recommended Citation}

Eisenberg, Theodore, "The Origins, Nature, and Promise of Empirical Legal Studies and a Response to Concerns" (2011). Cornell Law Faculty Publications. Paper 974.

http://scholarship.law.cornell.edu/facpub/974

This Article is brought to you for free and open access by the Faculty Scholarship at Scholarship@Cornell Law: A Digital Repository. It has been accepted for inclusion in Cornell Law Faculty Publications by an authorized administrator of Scholarship@Cornell Law: A Digital Repository. For more information, please contact jmp8@cornell.edu. 


\title{
THE ORIGINS, NATURE, AND PROMISE OF EMPIRICAL LEGAL STUDIES AND A RESPONSE TO CONCERNS
}

\author{
Theodore Eisenberg*
}

This Article describes the origins of three movements in legal academia: empirical legal studies (ELS), law and society, and law and economics. It then quantifies the distribution across scholarly fields (for example, economics and psychology) of authors in these movements' journals and reports the impact of the movements' scholarly journals. By focusing on two leading law and economics journals, this Article also explores the effect of a journal being centered in law schools rather than in a social science discipline. It suggests that ELS has achieved rapid growth and impact within the academic legal community because of (1) its association with law schools, and (2) its receptiveness to contributions by scholars from all social science disciplines. Concerns about the quality and growth of ELS are found to lack persuasive support.

What is empirical legal studies (ELS) and where did it come from? These questions are worth asking because, in a few years, ELS expanded from an unstructured enterprise without central loci, to include a journal (the Journal of Empirical Legal Studies (JELS)), to include what has become perhaps the largest annual refereed academic legal conference in the world (the Conference on Empirical Legal Studies (CELS)), to include a scholarly society (the Society for Empirical Legal Studies (SELS)), and to include, of course, at least one blog. ${ }^{1}$ It is international, with ELS conferences conducted outside of the United States in Israel,

* Henry Allen Mark Professor of Law and Adjunct Professor of Statistical Sciences, Cornell University. Portions of an earlier version of this paper were presented as part of a keynote speech at the Asian Law and Economics Association Meeting, August 23-24, 2010, Beijing, and an earlier version of this paper will appear in Hebrew in the Tel Aviv University Law Review. I would like to thank Shari Seidman Diamond, Carrie Menkel-Meadow, and Joshua Wright for comments and Matthew Heise for excellent research assistance.

1. See Empirical Legal Stud., http://www.elsblog.org/ (last visited July 25, 2011). 
Germany, Taiwan, Italy, and England. ${ }^{2}$ It is instructional, with scholars at (at least) Washington University, Northwestern University, the University of Illinois, and Cornell University instructing law professors in empirical methods and additional schools training law students. ${ }^{3}$ ELS is reified in visible settings, such as The Oxford Handbook of Empirical Legal Research, ${ }^{4}$ an excellent casebook, ${ }^{5}$ and as the theme of an Association of American Law Schools meeting. ${ }^{6}$ Centers of empirical legal studies have been established at (at least) University of California, Los Angeles, Cornell, Washington University, Harvard, and Berkeley. ${ }^{7}$ Additional schools, Texas, New York University (NYU), the University of Southern California, Yale, Northwestern, and Stanford have hosted or are scheduled to host CELS. Schools feature scholars doing empirical work in reports to alumni. The Wisconsin New Legal Realism Project relates to ELS as it seeks "to develop an interdisciplinary paradigm for empirical research on law." ELS is the object of studies of its rapid growth. ${ }^{9}$ Given the interest in and importance of ELS, this Article addresses aspects of its origins, relation to other disciplines, and impact.

2. See, e.g., Christoph Engel \& Urs Schweizer, Jurimetrics: 27th International Seminar on the New Institutional Economics June 11-13, 2009, Kloster Eberbach, Germany, 166 J. INST. \& THEORETICAL ECON., Mar. 2010, at 1; Jason Czaruezki, An Announcement from the UK, EMPIRICAL LEGAL STUD. (Oct. 23, 2007, 8:15 PM), http://www.elsblog.org/the_empirical_legal_studi/2007/10/anannouncement.html; Michael Heise, First International Conference on Empirical Studies of Judicial Systems, EMPIRICAL LEGAL STUD. (July 1, 2008, 7:49 PM), http://www.elsblog.org/the_empirical_ legal_studi/2008/07/my-cornell-coll.html; Conference Itenarary, International Conference: Empirical Legal Studies (Mar. 26, 2009), http://www.law.tau.ac.il/Eng/_Uploads/dbsAttachedFiles/Empirical LegalStudiesINV.pdf.

3. See, e.g., Empirical Scholarship Workshops, Nw. U. SCH. L., http://www.law.northwestern. edu/faculty/empiricalworkshop/ (last visited July 25, 2011).

4. See The OXford HandBook of Empirical Legal Research (Peter Cane \& Herbert M. Kritzer eds., 2010).

5. See Robert M. Lawless et Al., Empirical Methods in Law (2010).

6. Tracey E. George, An Empirical Study of Empirical Legal Scholarship: The Top Law Schools, 81 IND. L.J. 141, 142 (2006).

7. See, e.g., Leslie A. Gordon, The Empiricists: Legal Scholars at the Forefront of Data-Based Research, 82 STAN. LAW. (May 11, 2010), http://stanfordlawyer.law.stanford.edu/2010/05/theempiricists/; Linda Brandt Myers, The Journal of Empirical Legal Studies: Finding the Facts that Challenge Our Assumptions About the World, 34 CORNELL L.F., Spring 2008, at 10, http://www.lawschool. cornell.edu/research/upload/Spring2008LawForum2.pdf.

8. The New Legal Realism Project, U. WIS. L. SCH., http://www.law.wisc.edu/ils/newlegal. htm (last updated Oct. 28, 2009). "The Project's goal is to develop rigorous, genuinely interdisciplinary approaches to the empirical study of law." Id. (follow the link to the NLR homepage); see also Mark C. Suchman \& Elizabeth Mertz, Toward a New Legal Empiricism: Empirical Legal Studies and New Legal Realism, 6 ANN. REv. L. \& Soc. SCI. 555 (2010) (noting the return of interest in empirical legal research within the U.S. legal academy).

9. Shari Seidman Diamond \& Pam Mueller, Empirical Scholarship in Law Reviews, 6 ANN. REV. L. \& Soc. SCI. 581, 587 (2010) (showing that nearly half (45.8\%) of a sample of law review articles from 1998 to 2008 included some empirical content, but only $5.7 \%$ presented original empirical research); Michael Heise, An Empirical Analysis of Empirical Legal Scholarship Production, 19902009, 2011 U. ILL. L. REV. 1739, 1746 fig.2 (showing substantial growth in empirical legal scholarship from 2000 to 2009). For a description of ELS work and growth in the area of alternative dispute resolution, and salient observations about baseline reference points, see Carrie J. Menkel-Meadow, Dispute Resolution, in THE OXFORD HANDBOOK OF EMPIRICAL LEGAL RESEARCH, supra note 4, at 596, 599. 


\section{ORIGINS}

ELS has emerged without godfather-like external grants, such as the financing of law and society activity by the Russell Sage Foundation and the Walter E. Meyer Foundation, and the financing of law and economics activity by the Olin Foundation. ${ }^{10}$ Internal law school funds have supported JELS and CELS, with SELS member dues and conference fees also contributing in recent years. Because origins tend to influence subsequent practice, I describe here the origins of three major independent academic associations involved in law-related empirical work - the Law and Society Association (LSA), the American Law and Economics Association (ALEA), and SELS. Limiting the discussion to these groups necessarily excludes many other important institutions conducting ELS and is not meant to downplay the importance of those institutions. At least two other entities, the Law and Courts section of the American Political Science Association, and the American Psychology-Law Society of the American Psychology Association, are involved in similar work but are parts of larger organizations within their disciplines, with institutional structures largely separate from law schools. Other prominent organizations, not part of large, formal educational institutions, have been doing law-related empirical work for decades. These include the American Bar Foundation, the Research and Development (RAND) Institute for Civil Justice, the National Center for State Courts, the Federal Judicial Center, and the Bureau of Justice Statistics. For reasons of space and knowledge, I do not review here the origins of other institutions around the world engaged in related activities.

\section{A. Law and Society Association and Review}

Over forty years ago, the first issue of the Law \& Society Review (LSR) articulated a role that might reasonably apply to SELS. LSA's President, Robert B. Yegge, stated the new Society's role: "The idea of an interdisciplinary association of people in law and the social sciences becomes concretely visible with this, the first issue of the Law and Society Review." 11 The Society's journal was meant to be broadly inclusive of social science disciplines. LSR's first editor, Richard D. Schwartz, noted work by political scientists studying the implementation of legal decisions as being a new area for them, beyond the traditional studies of the processes of courts and legislatures. Sociologists, he observed, were showing increased interest in the legal process, and their "studies have been concerned with the manner in which the population is affected by

10. Steven M. Teles, The Rise of the Conservative Legal Movement: The Battle for CONTROL OF THE LAWS 183-87 (2008) (describing the Olin Foundation financing); H. Lawrence Ross, Programs in Law and Social Science, LAW \& SOC'Y REV. 509, 509 (1968) (describing the law and society financing).

11. Robert B. Yegge, The Law and Society Association to Date, 1 LAw \& Soc'Y REV. 3 , 3 (1966). 
law in such areas as civil rights, poverty, and crime."12 $\mathrm{He}$ also observed that other professional groups, "notably economists, social workers, clinical and social psychologists, and psychiatrists-are increasingly called upon for information thought to be of value in the formulation of legal policy." 13

Despite this broad statement, LSA's roots were planted largely by sociologists. Those roots manifest themselves today, as shown in Part III below, by the dominance of sociology in LSR. The Society began when about one hundred sociologists attended the 1964 Montreal meeting of the American Sociological Association. "The Association was there transformed from an idea to a reality." rated in 1964, ${ }^{16}$ a few years before the first issue of LSR - and LSR was clearly the Society's journal. ${ }^{17}$

\section{B. American Law and Economics Association}

ALEA's roots were more expressly ideological, at least on the part of its principal funder, than either LSA or SELS. The Olin Foundation "believed that law and economics represented a rare crack in the liberal legal network, a beachhead for conservatives otherwise locked out of the elite legal academy." 18

The Foundation's support was critical in inserting law and economics into the elite academic mainstream. "Especially important in moving law and economics from a barely tolerated minority to a dominant presence in legal academia was the Olin Foundation's two-decade-long investment in law and economics programs at the top-ranked law schools in the country." ${ }^{, 19}$ Olin was prescient in its support of some faculty members, including associations with some whom, in my opinion, occasionally seem to employ questionable statistical principles when presenting a point of view on policy matters. ${ }^{20}$ Olin, however, did not insist on ideo-

\footnotetext{
12. Richard D. Schwartz, From the Editor ..., 1 LAW \& SOC'Y REV. 6, 6 (1966).

13. Id.

14. Yegge, supra note 11, at 3.

15. Id.

16. Id.

17. Id. at 4

18. TELES, supra note 10, at 182.

19. Id.

20. George L. Priest, Ctr. for Legal Pol'y, What We Know and What We Don't Know About Modern Class Actions: A Review of the Eisenberg-Miller Study 2-3 n.14 (2005) (describing my transforming skewed dollar amounts to a logarithmic scale as a "numerical manipulation" and claiming that I had not answered this criticism). It is correct that I had not expressly addressed this criticism because some criticisms are unworthy of response. For a primer on the statistical basis for transforming skewed amounts, see Theodore Eisenberg \& Martin T. Wells, The Significant Association Between Punitive and Compensatory Damages in Blockbuster Cases: A Methodological Primer, 3 J. EMPIRICAL Legal Stud. 175 (2006), or almost any basic statistics book. Professor Priest refers to my work on punitive damages as having generated similar criticism. PRIEST, supra, at 2-3 n.14 (noting particular criticism of my work on punitive damages). Law and economics scholar W. Kip Viscusi has since employed both the logarithmic approach to regression models of punitive dam-
} 
logical purity, and its program in law schools has funded activities of many scholars without tests of their political leanings. ${ }^{21}$ But the conservative roots of law and economics funding and scholars created a reaction ranging from suspicion to open hostility, a reaction evidenced today by the shortage of economists involved in LSA activities. ${ }^{22}$

Putting aside its ideological funding dimension, ALEA, like SELS, was preceded by the existence of a related journal, in this case the Journal of Law and Economics (JLE). Judge Richard Posner is the most visible and cited figure in American Law and Economics. ${ }^{23}$ But before Richard Posner, there was Nobel prize-winning economist Ronald Coase, and before Ronald Coase, there was Aaron Director. Coase's article setting forth the Coase Theorem could be viewed as the foundation of modern law and economics. ${ }^{24}$ Director played a central role in the development of law and economics at the University of Chicago (Chicago), and his influence increased with the creation of $\mathrm{JLE}^{25}$ established in 1958, before LSR, JELS, the Journal of Legal Studies at the University of Chicago (JLS), or ALER. Coase observed that he doubted he would have gone to Chicago had there not been a JLE. ${ }^{26}$ Coase and Director were instrumental in attracting Posner to Chicago from Stanford. ${ }^{27}$ ALEA, founded in 1991, was an outgrowth of the law and economics movement, and started the Association's journal, ALER, in $1999{ }^{28}$

ages and other aspects of my work in evaluating punitive damages. See Alison F. Del Rossi \& W. Kip Viscusi, The Changing Landscape of Blockbuster Punitive Damages Awards, 12 AM. L. \& ECON. REv. 116, 143-52 (2010) (using logarithms in analyzing punitive damages and employing a variable, first suggested in Eisenberg and Wells, supra, to account for tobacco cases). I should add, as did Professor Priest, that we are former colleagues and remain friends. PRIEST, supra, at 2 n.9.

21. Nevertheless, troublesome evidence may exist that Olin terminated programs in part based on ideological grounds. Thomas O. McGarity, A Movement, A Lawsuit, and the Integrity of Sponsored Law and Economics Research, 21 STAN. L. \& POL'Y REV. 51, 64 n.114 (2010).

22. See Emma Coleman Jordan \& Angela P. Harris, Economic Justice: Race, Gender, IDENTITY AND ECONOMICS at v (2d ed. 2011) (expressing the view that law and economics "focuses on questions of transactional efficiency and tends to ignore questions of distribution or of justice" but noting that law and economics "has begun to alter its once iron-clad assumption that people always act as rational maximizers").

23. For example, Judge Posner was the first recipient of the American Law and Economics Association Coase medal. See The Coase Medal, 12 AM. L. \& ECON. Rev. 263 (2010).

24. R.H. Coase, The Problem of Social Cost, 3 J.L. \& ECON. 1 (1960).

25. TELES, supra note 10 , at 95 .

26. Id. at 96 .

27. Id. at $97-98$.

28. The American Law and Economics Review, AM. L. \& ECON. Ass'N, http://www.amlecon.org/ review.html (last visited July 25, 2011) [hereinafter The American Law and Economics Review]. 


\section{Society for Empirical Legal Studies}

In the case of ELS, the origins of the journal and society are reversed. JELS was first published in 2004. ${ }^{29}$ Its origins were narrower than LSR and ALER in the sense that it was largely the initiative of a single school. Lee Teitelbaum, the late Dean of Cornell Law School, is the person who ultimately convinced me to start JELS. But Dean Teitelbaum was not alone. His suggestion followed that of his predecessor, Dean Russell Osgood, who had also suggested starting a journal relating to ELS. I was not eager to do so because I enjoy producing scholarship more than administering and felt that running a journal would involve substantial administration. It was at an LSA meeting, in Budapest in 2001, that Dean Teitelbaum said something that led me to start JELS. He stated that, as Dean, he did not see why a law school should not support a faculty-edited journal to the same extent it supported a studentedited journal. That remark led me to think that pursuing a journal would be a reasonable idea.

Blackwell Publishers, now part of John Wiley \& Sons, Inc., agreed to publish JELS, but before doing so asked if it would be the official journal of a scholarly society. I was not interested in trying to start a movement or a society and said that I might try to form a society if there were sufficient interest in JELS but that JELS would have to come first. I incorrectly thought the lead time between JELS and a society would be several years. The first issue of JELS appeared in 2004. ${ }^{30}$ Bernard Black, then at the University of Texas School of Law, sensed the moment better than most of the rest of those already involved, and proposed the first ELS conference. An informal group of organizers conferred frequently about that first CELS, which was held at Texas in 2006. The original group consisted of Black (now at Northwestern), Jennifer Arlen (NYU), Michael Heise (Cornell), Geoffrey Miller (NYU), and me (Cornell). Before the first conference, the NYU and Cornell participants asked their Deans, Richard Revesz (NYU) and Stewart Schwab (Cornell), if they would sponsor the next two CELS conferences; Black had successfully pursued that issue at Texas. Both Deans agreed and, from the beginning, at least three schools committed to host CELS.

Under Black's leadership, we organized the first CELS conference, which succeeded beyond expectations. We did not know whether to expect twenty, fifty, or more paper submissions. We received more than a hundred, and attendance at the first CELS exceeded two hundred people. $^{31}$ Interest in empirical work and related institutions accelerated beyond its already rapid pace, and the last four CELS conferences, as of

29. See Journal of Empirical Legal Studies: Journal Information, WILEY, http://www.wiley.com/ bw/aims.asp?ref=1740-1453\&site=1 (last visited July 25, 2011).

30. Id.

31. For information about the first conference, see Conference on Empirical Legal Studies, U. TEX. L. SCH., http://www.utexas.edu/law/conferences/cels2006/ (last visited July 25, 2011). 
this writing, all exceeded three hundred attendees with at least two exceeding four hundred attendees. ${ }^{32}$ The most recent CELS conference, as of this writing, was held at Yale Law School in November 2010 and, based on my analysis of the attendee list handed out at the conference, included participants from most social science disciplines who came from at least sixteen countries.

\section{RELATION TO OTHER DISCIPLINES}

Such substantial activity tempts one to try to locate ELS in the spectrum of interdisciplinary legal movements. Despite its prominence, ELS is not, in my view, a competitor with other "law and" social science disciplines. It is complementary to them and helps the study of law and the legal system to join part of a larger probabilistic revolution. That revolution has been said to encompass "the web of changes that made probability a part of philosophy, scientific theories and practice, social policy, and daily life between circa 1800 and 1950, ${ }^{, 33}$ and has obviously been accelerated by the growth of personal computing. ${ }^{34}$ ELS scholars use tools that have long been used in and out of law schools. ELS employs a methodology that is usually, but not always, the methodology of statistical analysis - parts of which are used by most scholars with a social scientific interest in legal issues.

Traditionally these scholars have training in a social science such as economics, psychology, health care, policy, political science, criminology, finance, or sociology. With scholars from several disciplines doing empirical work, much of the empirical study of law was segmented across varying disciplines with no center. Despite the pre-ELS disciplines' common enterprise of studying law-related issues, they sometimes competed and even denigrated one another, as in the isolation of law and economics from law and society. ${ }^{35}$ The growth of ELS has given lawrelated empirical scholarship a center, albeit a diffuse center, in law schools, in conferences, in a journal, and in other activities without sacrificing the distinct contribution of each discipline engaged in empirical scholarship. ELS's multidisciplinarity emerges in the credentials of organizers of the annual CELS. The first five conferences were run by

32. For an example of a recent CELS program, see Conference on Empirical Legal Studies, YALE L. SCH., http://www.law.yale.edu/news/CELSprogram.htm (last visited July 25, 2011).

33. Lorenz Krüger, Preface to Volumes 1 and 2, in 1 THE Probabilistic ReVOLUTION: IDEAS IN HISTORY, at Xv (Lorenz Krüger et al. eds., 1987).

34. For a broad perspective on statistics in modern times, see generally the articles in STATISTICS IN THE 21ST CENTURY (Adrian E. Raftery et al. eds., 2002) (containing articles addressing statistical issues across many disciplines). For a perspective on empirical methods and the law, see Theodore Eisenberg, Empirical Methods and the Law, 95 J. AM. STAT. Ass'N 665 (2000) (reprinted in STATISTICS IN THE 21ST CENTURY, supra, at 179).

35. See Victoria Nourse \& Gregory Shaffer, Varieties of New Legal Realism: Can a New World Order Prompt a New Legal Theory?, 95 CORNELL L. REV. 61, 64 (2009) (suggesting that new legal realism offers an alternative to a new formalism represented by the theory of neoclassical law and economics). 
scholars with training in economics, psychology, political science, policy, and history, as well as by scholars with only legal training.

Although I see no great harm in viewing it as such, I would not describe ELS as simply a successor to legal realism, which achieved prominence in some law schools from about the 1920s through the 1940s. Legal realism cannot be captured by a single belief, but a core feature was the value of social science-oriented interdisciplinary approaches to law. ${ }^{36}$ Social science methods usually involve the analysis of data, thus suggesting a realism-ELS link. ELS cannot be viewed as succeeding this aspect of legal realism, because legal realism has never left. ${ }^{37}$ As Professor Kritzer has noted, a significant portion of early ELS work was connected to the legal realism movement. ${ }^{38}$ In addition, the empirical ambitions of legal realism went largely unrealized ${ }^{39}$ and were partly succeeded by the movements in law and society and law and economics.

What ELS research shares with predecessors and current associated fields is open to debate, but a core principle seems indisputable: it is better to have more systematic knowledge of how the legal system works rather than less, regardless of the normative implications of that knowledge. This modest principle drives much ELS work, but no single principle can capture the motivation of the many scholars engaged in ELS. The pursuit of systematic knowledge is, I think, what makes ELS studies often attract the interest of policy makers and the media.

Although ELS is more evolutionary than revolutionary, its rapid ascendance does have a revolutionary feel to it, enough to startle some observers. According to one blog pundit "the empirical fetish has now gotten out of control." ${ }^{41}$ And, like revolutions, ELS has generated aspects of counterrevolution. It is claimed that "there is now too much empirical 337.

36. See, e.g., Howard Erlanger et al., Is It Time for a New Legal Realism?, 2005 WIS. L. REV. 335,

37. See Brian Z. Tamanaha, Understanding Legal Realism, 87 TeX. L. REV. 731, 734 (2009) ("We are all realists now." (quoting George Packer, Comment, Unrealistic, NEW YORKER, Nov. 27, 2006, at $83,83))$.

38. Herbert M. Kritzer, Empirical Legal Studies Before 1940: A Bibliographic Essay, 6 J. EMPIRICAL LEGAL STUD. 925, 926 (2009) [hereinafter Kritzer, Empirical Legal Studies]. A milestone in the foundation of modern ELS was the Wisconsin Civil Litigation Research Project (CLRP). David M. Trubek et Al., Civil Litigation Research Project: FinAl Report (1983) (studying litigation processes, outcomes, and costs based on data from federal courts, state courts, and surveys of lawyers and households). For a sample of the work growing out of the CLRP, see Herbert M. Kritzer, Bibliography of Publications and Papers of the Civil Litigation Research Project, http://users.polisci. wisc.edu/kritzer/research/clrpbib.htm (last updated Dec. 18, 2004). For a recent discussion of the history of empirical research in the area of civil procedure, see Carrie J. Menkel-Meadow \& Bryant Garth, Civil Procedure and Courts, in THE OXFORD HANDBOOK OF EMPIRICAL LEGAL RESEARCH, supra note 4 , at $679,683-90$.

39. George, supra note 6, at 145 .

40. Kritzer, Empirical Legal Studies, supra note 38, at 925 (noting that the origins of ELS predate both the law and society and law and economics movements).

41. Brian Leiter, On So-Called "Empirical Legal Studies" and Its Problems, BRIAN LEITER's L. SCH. REP. (July 6, 2010, 6:41 AM), http://leiterlawschool.typepad.com/leiter/2010/07/on-socalledempirical-legal-studies.html. 
work being done simply because it looks 'empirical." ${ }^{42}$ The sources of the ELS problem are said to be two-fold. First, "too much of the work is driven by the existence of a data set, rather than an intellectual or analytical point." ${ }^{43}$ Second, the skill level "of ELS scholars appears to be, on average, low, or at least lower than the typical law \& economics or law \& philosophy interdisciplinary scholar of yesteryear." ${ }^{44}$

Aspects of these concerns are implicitly or explicitly addressed in Part III, but some summary thoughts may be helpful here. One hesitates to attribute much weight to blog posts since they often constitute unreflective, on-the-spot reactions provided to promote or provoke discussion. The above views nevertheless may represent reactions to ELS of some segment of the legal academy and therefore are worth commenting on.

The assertion that ELS scholars are relatively less skilled than the other "law and" groups is not self-evidently true. As shown below, most ELS scholarship is conducted by those with formal training via a $\mathrm{PhD}$ in another discipline, and ELS scholars have sometimes improved the work of highly regarded scholars in other fields. Many law and economics scholars have no advanced degree in economics and many practitioners of law and philosophy or jurisprudence also lack relevant advanced degrees. Thus, the claim that ELS scholars are on average less skilled requires more than bare assertion to be credible.

Most importantly, the counterrevolutionary comments suggest a world divided into ELS scholars and other scholars, in which the two groups are engaged in a zero sum game. In this view, ELS scholarship comes at the cost of scholars doing other important work. That is a false dichotomy because excellent ELS work is done by scholars who are primarily nonempirical in their focus, and much of their empirical work comes not at the expense of nonempirical scholarship, but as an addition to it. ${ }^{45}$ Scholars teaching legal doctrine often encounter questions with an empirical component. To not pursue those questions because one is told there is too much empirical scholarship would be unfortunate. To perhaps frighten untenured faculty members away from empirical work through unsupported fetish claims is troublesome.

The simplistic attack on ELS may also compromise the intellectual growth of nonempirical scholars. My impression is that the many doctrinalists I have worked with believe that their nonempirical scholarship, as well as their ability to understand and critique empirical scholarship, im-

\footnotetext{
42. $I d$.

43. $I d$.

44. Id.

45. See, for example, Benjamin Barton's prize-winning article on the relation between teaching and scholarship. Benjamin Barton, Is There a Correlation Between Law Professor Publication Counts, Law Review Citation Counts, and Teaching Evaluations? An Empirical Study, 5 J. EMPIRICAL LegaL STUD. 619 (2008). The article won the 2010 Law School Admission Council Philip D. Shelton Award for outstanding research in legal education.
} 
prove as the result of having participated in empirical projects. They gain new perspectives on problems and are more informed consumers of a broader range of scholarship. This synergy could be jeopardized if many scholars take seriously the naked assertion that there is too much ELS.

\section{IMPACT OF EMPIRICAL LEGAL STUDIES}

ELS's origins have been accompanied by the surprisingly quick impact of its two primary institutions, CELS and JELS. As noted above, CELS may already be the largest academic conference of its kind. ${ }^{46}$ With respect to ELS studies' impact, it is helpful to separate components within academia and outside of academia. The within-academia component is of interest to scholars while the second component has demonstrated, and can continue to demonstrate, ELS's useful role in bridging the oftenbemoaned gap between academia and law practice.

\section{A. Producers of Empirical Legal Studies and Their Impact in the Academy}

One measure, but of course not the only measure, of ELS's academic impact is the influence of its core journal, JELS. The growth of CELS and the maturing of JELS seem to have had a synergistic effect, with interest in and citations to JELS ${ }^{47}$ growing at an unexpected (at least to me) pace for a journal so recently founded. As described above, JELS's success played a role in the early proposal for a conference, which led to a society. ${ }^{48}$ So the patterns of authors and impact of JELS and related organizations' journals are worth describing.

To study who is producing ELS in JELS, I compared the field of study of the lead authors of articles with the fields of study of lead authors of articles in two other leading peer-reviewed journals. JLS and LSR are two of the most prominent peer-reviewed, law-related journals, both of which publish empirical scholarship (as well as other kinds of scholarship). These journals are not the only serious producers of ELS. One could also compare JELS authors' disciplines with the disciplines of authors who published in, for example, Law and Social Inquiry or American Law and Economics Review.

Table 1 shows the distribution by field of study of the lead author of articles published in JELS, JLS, and LSR since JELS's origin in 2004. For purposes of this analysis, I assigned authors to fields based on their $\mathrm{PhD}$ or other advanced degree. For example, a scholar who teaches in a law school but has a doctorate in economics would be listed under eco-

\footnotetext{
46. See supra note 1 and accompanying text

47. See infra Table 1.

48. See supra Part I.C.
} 
nomics in this table, regardless of whether the scholar was teaching in a law school or some other academic department. The information about nonlaw degrees comes from the institutional information in the first footnote of articles and from searches of other articles or internet sites where additional information was required.

TABLE 1:

LEAD AUTHOR’s FIELD OF STUDY, THREE JOURNALS, 2004-2010

Lead author

field of study

\begin{tabular}{cccccc}
$\begin{array}{c}\text { Journal of Empirical } \\
\text { Legal Studies }\end{array}$ & \multicolumn{2}{c}{$\begin{array}{c}\text { Journal of Legal } \\
\text { Studies }\end{array}$} & \multicolumn{2}{c}{$\begin{array}{c}\text { Law \& Society } \\
\text { Review }\end{array}$} \\
\hline $\begin{array}{c}\text { Number } \\
\text { of } \\
\text { articles }\end{array}$ & $\begin{array}{c}\% \text { of } \\
\text { articles }\end{array}$ & $\begin{array}{c}\text { Number of } \\
\text { articles }\end{array}$ & $\begin{array}{c}\% \text { of } \\
\text { articles }\end{array}$ & $\begin{array}{c}\text { Number of } \\
\text { articles }\end{array}$ & $\begin{array}{c}\% \text { of } \\
\text { articles }\end{array}$ \\
\hline 0 & $0.0 \%$ & 0 & $0.0 \%$ & 11 & $6.0 \%$ \\
42 & $24.4 \%$ & 82 & $62.6 \%$ & 7 & $3.8 \%$ \\
63 & $36.6 \%$ & 36 & $27.5 \%$ & 14 & $7.7 \%$ \\
12 & $7.0 \%$ & 2 & $1.5 \%$ & 0 & $0.0 \%$ \\
4 & $2.3 \%$ & 4 & $3.1 \%$ & 14 & $7.7 \%$ \\
24 & $14.0 \%$ & 5 & $3.8 \%$ & 55 & $30.2 \%$ \\
12 & $7.0 \%$ & 2 & $1.5 \%$ & 6 & $3.3 \%$ \\
8 & $4.7 \%$ & 0 & $0.0 \%$ & 74 & $40.7 \%$ \\
7 & $4.1 \%$ & 0 & $0.0 \%$ & 1 & $0.5 \%$ \\
\hline \hline 172 & $100 \%$ & 131 & $100 \%$ & 182 & $100 \%$ \\
\hline
\end{tabular}

Although all three journals show dispersed sources of contributions by discipline, noticeable differences exist. JELS is the least concentrated based on a journal's two most dominant disciplines. About seventy percent of LSR contributions come from sociology or political science (which includes government departments). About ninety percent of JLS contributions come from economics (which includes finance) or law. These concentrations both exceed the sixty percent of JELS contributions that come from law or economics. JELS is the only journal of the three with the modal contribution coming from scholars primarily trained in law.

Scholars with only formal legal training play a surprisingly minor role as lead authors in LSR. Its 1960s roots as the journal of an organization founded by sociologists have continued to shape its content. Although LSR's founders articulated an interest in all the social sciences, the wide interest in law and economics of the past thirty-five or so years is not reflected in LSR. Of the few economics-trained scholars who have published in LSR, almost all have law school appointments. The minor 
role of psychologists in LSR is also surprising to me. ${ }^{49} \mathrm{JLS}$ is even more dominated by scholars trained in economics than is LSR by scholars trained in sociology. These results do not seem sensitive to my methodology because the comparative JELS/LSR results in Table 1 are consistent with those reported by Mark Suchman and Elizabeth Mertz using a smaller sample of articles.

How do the distributions of scholars by discipline influence the impact of a journal? The impact of journals that do not prominently feature authors with law degrees is difficult to compare with journals more centered in legal academia. For LSR, for example, one suspects that its major impact would be in the sociology literature. For ALER and JLE, one suspects a similar effect in economics literature. But even this expectation can be complicated by the competitive environment for the journals in their dominant discipline. As economics journals, ALER and JLE compete for articles related to law with American Economic Review, the Journal of Political Economy, Quarterly Journal of Economics, Review of Economics and Statistics, and other leading journals. As a predominantly sociology journal, LSR competes with leading sociology journals that do not focus primarily on law-related scholarship.

To evaluate journals' impact, I use the Washington and Lee Law Library database (W\&L), which includes over 1000 law-related journals and uses citations in Westlaw's database to assess impact. ${ }^{51}$ W\&L has the useful feature of enabling one to distinguish among journals by lawrelated subject area, and by whether a journal is refereed by peers rather than by students. A limitation of the W\&L data is that its use of Westlaw limits the citations it includes to those in law-related journals. So citations of economics or sociology journals in nonlaw journals are not included. One cannot regard citations in the Westlaw database as an overall measure of economics or sociology journals; they are better viewed as a measure of impact in law-related outlets.

To explore one aspect of the effect of being centered in law schools, I compare the impact of the two journals in Table 1 that have the largest and smallest percentages of law-trained authors, JELS and LSR. Note

49. Suchman \& Mertz report that psychology is a surprisingly minor contributor to both JELS and LSR. Suchman \& Mertz, supra note 8, at 570.

50. Id. (showing greater participation by economists in JELS and by political scientists and anthropologists in LSR). For one difference in methodology from this article, see $i d$. at 569 n.10.

51. See Law Journals: Submission and Ranking, WASH. \& LEE U. SCH. L., http://lawlib.wlu. edu/lj/ (last visited July 25, 2011) [hereinafter W\&L]. The journal ranking system often used for nonlaw disciplines is based on a journal's impact factors in the system operated by what was originally the Institute for Scientific Information (ISI) and is now part of Thomson Reuters. Daniel B. Klein \& Eric Chiang, The Social Science Citation Index: A Black Box-with an Ideological Bias?, 1 ECON. J. WATCH 134, 135 (2004). But key ISI products, such as the Social Science Citation Index (SSCI) and Journal Citation Reports (JCR), are virtually unknown to U.S. law professors, have not, to my knowledge, been used by law schools to evaluate legal scholarship and contain a much narrower range of lawrelated journals than other sources. Online probing of JCR suggests that it includes 128 law journals. ISI Web of Knowledge, THOMSON REUTERS (on file with author) (list of journals from subject category "Law"). Databases such as Westlaw and Lexis include several times that number. 
that the "Totals" row for the "Number of Articles" columns in Table 1 show that the two journals have published similar numbers of articles during the period studied. If one assesses impact based on the W\&L rankings, both JELS and LSR are reasonably well-ranked journals. Table 2 shows the ordinal rankings of the two journals for three years, divided into two subgroups. Panel A limits the sample to those journals identified in the W\&L database as social science journals. Panel B limits the sample to those journals identified in the W\&L database as refereed. Both limitations effectively exclude student-edited journals. The rows in both panels of Table 2 are the five characteristics (labeled in the table as "Currency factor," "Cases," "Journals," "Impact factor," and "Combined") that the W\&L database uses to assess journals. ${ }^{52}$ Hence, each panel has five rows that report data, over time and by journal, as indicated by the column headings. Among social science journals, both JELS and LSR have a combined factor rating (the last row in each panel) in the top five. Among refereed journals, as shown in panel B, each has a combined factor rating in the top five percent.

These high rankings in one sense understate the journals' achievements because the category of refereed journals includes many journals with specific substantive-area foci. These journals generally do not seriously compete with LSR and JELS for empirically oriented articles. Because Westlaw is law based, and because LSR presumably has greater impact in the field of sociology, this methodology also understates LSR's overall impact, but probably is a reasonable proxy for its relative impact in the legal academic environment. JELS's more law-related focus likely also contributes to its higher rankings in currency of citations, citations in cases, and citations in journals. 
TABLE 2:

RANKING IN WASHINGTON AND LEE LAW LIBRARY SYSTEM OF JELS AND LSR

\begin{tabular}{|l|c|c|c|c|c|c|c|}
\hline & JELS & LSR & JELS & LSR & JELS & LSR \\
\hline \multicolumn{7}{|c|}{2009} & \multicolumn{2}{|c|}{2008} & \multicolumn{2}{|c|}{2007} \\
\hline A. Limited to Social Science journals (number of ranked social science journals » 20) \\
\hline Currency factor & 1 & 8 & 1 & 8 & 1 & 7 \\
\hline Cases & 1 & 2 & 1 & 2 & 1 & 1 (tie) \\
\hline Journals & 3 & 2 & 5 & 2 & 7 & 2 \\
\hline Impact factor & 2 & 6 & 1 & 6 & 1 & 6 \\
\hline Combined & 1 & 4 & 1 & 4 & 1 & 4 \\
\hline B. Limited to refereed journals (number of ranked refereed journals » 531) & 26 \\
\hline Currency factor & 1 & 40 & 1 & 34 & 2 & 19 (tie) \\
\hline Cases & 5 & 21 & 7 & 18 & 19 & 12 \\
\hline Journals & 13 & 10 & 23 & 13 & 32 & 22 \\
\hline Impact factor & 4 & 26 & 2 & 24 & 3 & 14 \\
\hline Combined & 5 & 19 & 5 & 19 & 4 & \\
\hline
\end{tabular}

Note: JELS=Journal of Empirical Legal Studies; LSR=Law \& Society Review.

Currency factor: aims to compare journals on how rapidly their articles become cited.

Cases: based on the number of cases that cite to a journal (within W\&L designated date period). Journals: based on the number of articles that cite to a journal (within W\&L designated date period).

Impact factor: based on the average number of annual citations to articles in a journal. Combined: a composite of a journal's impact factor and total cites count. To fairly compare new journals with established journals an adjustment is made for journals which, at the survey date, have existed for less than eight years.

\section{B. What Is the Effect of a Journal Being Centered in Law Schools?}

JELS being centered in law school academia and LSR's centering in sociology do not provide the best measure of the importance of law school centering because the range of disciplines covered by the journals clearly differs. A more useful comparison might come from comparing two excellent journals in the same discipline, such as the economics journals JLE and ALER. As described above, no journal has played a more important historical role than JLE in promoting social scientific analysis in legal academia $;{ }^{53}$ Coase credits it in part with his presence at Chicago. ${ }^{54}$ JLE is the earliest scholarly journal precursor to the American Law and Economics Association, which now has its own journal, ALER. ALER is currently edited by two law school professors, Steven Shavell at Harvard and John Donohue at Stanford, and it is the official journal of

53. See supra Part I.B.

54. TELES, supra note 10, at 96-101. 
ALEA, an association administered out of Yale Law School. ${ }^{55}$ JLE has existed about forty years longer than ALER and is now a joint publication of Chicago's business and law schools and not directly associated with ALEA.

Based on these characteristics JLE and ALER are two journals emphasizing the same field-economics. Both are centered at elite institutions, Chicago and Harvard/Yale/Stanford, but they differ in their connections to legal academia. Table 3 shows the $\mathrm{W} \& \mathrm{~L}$ rankings of the two journals. Like Table 2, the table presents ranking results for the most recent three years available for each of the five W\&L citation factors. Despite its prominent role in the history of law and economics, and decadeslonger existence, JLE appears to have been passed by ALER in impact among legal academics. ALER is now likely more centered in law schools than JLE. I suspect that the differential centering has contributed to ALER's quick ascendancy in a law-school-dominated database relative to JLE. Centering in law schools likely leads to less technical articles on average and to topics likely of greater interest to legal academics and attorneys.

55. The American Law and Economics Review, supra note 28.

56. Journal of Law \& Economics, U. CHI. PRESS, http://ideas.repec.org/s/ucp/jlawec.html (last updated July 7, 2011). 
TABLE 3:

IMPACT IN LEGAL ACADEMIA OF JLE AND ALER

\begin{tabular}{|l|c|c|c|c|c|c|c|}
\hline & JLE & ALER & JLE & ALER & JLE & ALER \\
\hline \multicolumn{7}{|c|}{2009} & \multicolumn{2}{|c|}{2008} & \multicolumn{2}{|c|}{2007} \\
\hline A. Limited to Social Science journals (number of ranked social science journals » 20) \\
\hline Currency factor & 12 & 2 & 5 & 3 & 8 & 3 \\
\hline Cases & 3 & 4 & 2 & 4 & 3 & 3 \\
\hline Journals & 5 & 7 & 3 & 7 & 3 & 6 \\
\hline Impact factor & 10 & 3 & 7 & 3 & 7 & 3 \\
\hline Combined & 8 & 5 & 5 & 7 & 5 & 6 \\
\hline B. Limited to refereed journals (number of ranked refereed journals » 531) & 12 \\
\hline Currency factor & 46 & 16 & 21 & 16 & 29 & 22 \\
\hline Cases & 25 & 28 & 18 & 23 & 22 & 28 \\
\hline Journals & 26 & 34 & 18 & 32 & 16 & 26 \\
\hline Impact factor & 40 & 19 & 28 & 16 & 25 & 24 \\
\hline Combined & 34 & 24 & 25 & 22 & 24 \\
\hline
\end{tabular}

Note: JLE=Journal of Law \& Economics; ALER=American Law \& Economics Review.

Currency factor: aims to compare journals on how rapidly their articles become cited.

Cases: based on the number of cases that cite to a journal (within W\&L designated date period). Journals: based on the number of articles that cite to a journal (within W\&L designated date period).

Impact factor: based on the average number of annual citations to articles in a journal. Combined: a composite of a journal's impact factor and total cites count. To fairly compare new journals with established journals an adjustment is made for journals which, at the survey date, have existed for less than eight years.

\section{The Marginal Contributions of Empirical Legal Studies and the Limits of Some Critiques}

Despite the success of CELS and JELS, one should not overstate the contributions of ELS. I do not think ELS has led scholars trained in nonlaw disciplines necessarily to do work they would not otherwise have done. I do think ELS contributed to their activity by making those in law schools feel less peripheral within their schools, by acknowledging that social science work outside of law schools should be taken seriously by legal academics and integrated into their work, ${ }^{57}$ by providing scholarly outlets for ELS scholars, and by promoting interactions among the disciplines at the annual CELS and elsewhere.

I also believe the rise of ELS has contributed to law professors not trained in other disciplines conducting empirical research they might not otherwise have pursued. Although most scholars doing empirical work

57. As Suchman and Mertz observe, "[t]o disciplinary [nonlaw school] researchers, the legal academy can seem, at once, enticing yet aloof, dauntingly complex yet dismayingly naive." Suchman \& Mertz, supra note 8, at 566 . 
have training in nonlaw disciplines, empirical study of law is a tool that might be considered for use by any legal scholar when an empirical issue is of interest. This can be illustrated by its use by several of my Cornell Law School colleagues. When Professor Robert Hillman had a theory about the courts' treatment of promissory estoppel in contract law, he found it useful to study systematically how courts were treating that doctrine, and he found that a common belief about its increased use was not supported. $^{58}$ When Professor James Henderson sensed a substantial prodefendant shift in products liability law, he suggested we study systematically, at the trial and appellate levels, the trend in plaintiffs' success over time. $^{59}$ We found an antiplaintiff revolution in products liability law. ${ }^{60}$ When Professors Kevin Clermont and Stewart Schwab were interested in the fate of employment discrimination cases, they studied systematically how plaintiffs were faring and helped document the relative lack of success in such cases. ${ }^{61}$ Other examples include the capital punishment scholarship of Professors John Blume, Stephen Garvey, and Sheri Johnson. $^{62}$ None of these scholars does exclusively empirical work and for most of them empirical studies are a small part of their scholarly output.

Adding several law professors to those empirically studying the legal system is important because the system is difficult to understand and describe. In addition to law professors' superior knowledge of most aspects of the legal system, scholars with limited legal training sometimes misdescribe the system, as illustrated by inflated claims about the settlement rate for filed cases, ${ }^{63}$ or get the law wrong. ${ }^{64}$ Law professors can also contribute by directing studies towards aspects of the legal system that are understudied in particular social science disciplines. Although the U.S. Supreme Court is clearly worthy of much study, it is a small part of our legal system. On a day-to-day basis, state and federal trial courts, state and federal intermediate appellate courts, and state courts of last resort affect far more people than the U.S. Supreme Court, but are studied disproportionately less than the Supreme Court.

58. Robert A. Hillman, Questioning the "New Consensus" on Promissory Estoppel: An Empirical and Theoretical Study, 98 COLUM. L. REV. 580, 580-85 (1998).

59. James A. Henderson, Jr. \& Theodore Eisenberg, The Quiet Revolution in Products Liability: An Empirical Study of Legal Change, 37 UCLA L. REV. 479, 481 (1990); see also Theodore Eisenberg \& James A. Henderson, Jr., Inside the Quiet Revolution in Products Liability, 39 UCLA L. REV. 731, 734-35 (1992).

60. See generally sources cited supra note 59.

61. Kevin M. Clermont \& Stewart J. Schwab, How Employment Discrimination Plaintiffs Fare in Federal Court, 1 J. EMPIRICAL LEGAL STUD. 429, 429 (2004).

62. See, e.g., John H. Blume et al., An Empirical Look at Atkins v. Virginia and Its Application in Capital Cases, 76 Tenn. L. Rev. 625 (2009); Stephen P. Garvey et al., Juror First Votes in Criminal Trials, 1 J. EMPIRICAL LEGAL STUD. 371 (2004).

63. Theodore Eisenberg \& Charlotte Lanvers, What Is the Settlement Rate and Why Should We Care?, 6 J. EMPIRICAL LEGAL STUD. 111, 112 n.1 (2009) (citing studies that misstate the settlement rate).

64. See, e.g., Theodore Eisenberg, Measuring the Deterrent Effect of Punitive Damages, 87 GeO. L.J. 347, 347 (1998) (describing incorrect characterization of punitive damages laws). 
Critiques of ELS professors as being of below-average quality presume a standard of performance in other disciplines that may be unrealistic. For example, we all would like to think of medical studies as especially reliable. Yet a leading medical statistical primer states that "about half (or more) of the papers tentatively accepted for publication have statistical problems." ${ }^{65}$ Those are of course just the observable errors. When drug companies compromise science by withholding material information, ${ }^{66}$ the incorrect statistical analyses come on top of other untrustworthy results. By another measure, the fifty percent estimate of difficulty is conservative and may oversimplify by not distinguishing among kinds of studies. One summary of estimated error rates is as follows: " 80 percent of non-randomized studies (by far the most common type) turn out to be wrong, as do 25 percent of supposedly gold-standard randomized trials, and as much as 10 percent of the platinum-standard large randomized trials." ${ }^{, 67}$ Empirical analysis in economics has been the subject of concern and experienced a wave of critical appraisals, with optimism about improved practices recently expressed. ${ }^{68}$

Thus, merely by being candid and reasonably competent, ELS scholars may achieve or even exceed the average quality of some other disciplines. ELS scholars have made methodological contributions that should transcend ELS and improve the work of scholars with formal training in fields such as economics and political science. Before describing some of those contributions, note that methodological critiques by ELS and other scholars should be interpreted in the larger context of trying to contribute to knowledge. Empirical scholars in all disciplines can be viewed as supplying fodder for subsequent scholars to prove them wrong or to improve on their results. Nearly all data and results are limited by time and place, by techniques for gathering and analyzing data

65. Stanton A. Glantz, Primer of Biostatistics 7 (6th ed. 2005).

66. Gregory D. Curfman et al., Editorial, Expression of Concern: Bombardier et al., "Comparison of Upper Gastrointestinal Toxicity of Rofecoxib and Naproxen in Patients with Rheumatoid Arthritis,” 353 NEw ENG. J. MED. 2813, 2813-14 (2005); Gregory D. Curfman et al., Expression of Concern Reaffirmed, 354 NEw ENG. J. MED. 1193, 1193 (2006). Dr. Thomas A. Marciniak of the U.S. Federal Drug Administration reportedly stated that:

[D]octors in the [Avandia] study correctly took note of problems that patients in the study expe-

rienced only to have those initial judgments later overruled or questioned by the company. He said sick patients were dropped from the study instead being allowed to tarnish Avandia. "This is a great way to improve your mortality statistics, which everybody tells me can't be biased," he said.

Gardiner Harris, F.D.A Panel Votes to Restrict Avandia, N.Y. TIMES, July 14, 2010, http:// prescriptions.blogs.nytimes.com/2010/07/14/blogging-the-f-d-a-panel-on-avandia/.

67. David H. Freedman, Lies, Damned Lies, and Medical Science, ATlantic, Nov. 2010, http://www.theatlantic.com/magazine/archive/2010/11/lies-damned-lies-and-medical-science/8269/; see also John P.A. Ioannidis, Why Most Published Research Findings Are False, 2 PLOS MED. 0696, 0696 (2005), http://www.plosmedicine.org/article/info:doi/10.1371/journal.pmed.0020124 (follow "Download PDF" hyperlink) ("[F]alse findings may be the majority or even the vast majority of published research claims.").

68. Joshua D. Angrist \& Jörn-Steffen Pischke, The Credibility Revolution in Empirical Economics: How Better Research Design Is Taking the Con out of Econometrics, 24 J. ECON. PERSP., Spring 2010 , at 3, 6 (2010). 
that change, and by reinterpreting old results in light of additional evidence. The humbling truth is that probably nearly all ELS scholars, and probably all other data analysts, make mistakes or may be shown to be incorrect by subsequent research. This is in the nature of science and that science being conducted by humans.

Specific methodological contributions of ELS scholars can lead to more rigorous results across a range of disciplines. One important ELS article highlights the dangers of econometric models that employ massive numbers of dummy variables, raising issues of multicollinearity or numerical computational stability. ${ }^{69}$ Another article calls attention to the use of classification and regression trees (CART). ${ }^{70}$ CART can provide graphical insight into categorical and other data that may avoid relying on spurious regression results. ${ }^{71}$ Other ELS work reminds that even highly skilled analysts can sometimes neglect to control for the nonindependence of observations in a study. ${ }^{72}$ ELS studies have also highlighted the limitations of existing techniques for evaluating the influence of judges on case outcomes.

Ironically, the nature of scientific endeavor suggests that the complaint that ELS research is weak seems inconsistent with the same observer's claim that too much ELS research is being conducted. In many scientific fields, replication is valued and convergence of results is awaited before "truth" is accepted. ${ }^{74}$ Discouraging additional ELS research tends to assure that empirical findings will be less often replicated and therefore less reliable. This problem is compounded by a perhaps overly expansive concept of article preemption in law reviews, which limits opportunities for publishing replication studies.

69. William Anderson \& Martin T. Wells, Numerical Analysis in Least Squares Regression with an Application to the Abortion-Crime Debate, 5 J. EMPIRICAL LegAL STUD. 647, 649-64 (2008).

70. Jonathan P. Kastellec, The Statistical Analysis of Judicial Decisions and Legal Rules with Classification Trees, 7 J. EMPIRICAL LEGAL STUD. 202, 202-03 (2010).

71. See Theodore Eisenberg \& Geoffrey P. Miller, Do Juries Add Value? Evidence from an Empirical Study of Jury Trial Waiver Clauses in Large Corporate Contracts, 4 J. EMPIRICAL LEGAL STUD. 539, 574 (2007).

72. Charles R. Shipan, Partisanship, Ideology, and Senate Voting on Supreme Court Nominees, 5 J. EMPIRICAL LEGAL STUD. 55, 63-64 (2008) (accounting for the nonindependence of senatorial voting on Supreme Court nominees).

73. Jonathan P. Kastellec \& Jeffrey R. Lax, Case Selection and the Study of Judicial Politics, 5 J. EmPIRICAl Legal Stud. 407, 407-10 (2008); Denise M. Keele et al., An Analysis of Ideological Effects in Published Versus Unpublished Judicial Opinions, 6 J. EmPIRICAL Legal StUd. 213, 213-16 (2009).

74. E.g., Ioannidis, supra note 67 , at 0700 ("[M]ost research questions are addressed by many teams ...."). The same source notes that emphasizing the statistical significance of a particular team can be misleading. $I d$. 


\section{Tempering the Dominance of Disciplines and Departments}

Interdisciplinarity is in fashion, as it should be. Isolated endeavors within disciplines can miss the big picture. For example, increased medical specialization sometimes leaves the perception, at least in my experience, that no doctor feels ultimately responsible for the overall physical well being of a patient. Crossing disciplines is important in studying how the legal system works. Lawyers and law professors tend not to have social science training and social scientists sometimes lack the training to properly study the legal system without the knowledge of law-trained experts. A strength of ELS and JELS, though also sometimes a potential weakness, is the absence of the need for loyalty to a particular social science discipline. This promotes inquiry in both obvious and less obvious ways.

An obvious benefit of not having to align with a discipline's methodology is reduced conflict with other disciplines. As shown above, LSR, a sociologically oriented law journal seemingly founded as an outlet for all social science studies related to law, has been inactive in economics and is hardly an outlet for psychology. ${ }^{75}$ Scholars in these fields may be unwilling or unable to articulate a theoretical sociological paradigm for work primarily relating to other disciplines. Or the likely greater average conservatism of law and economics scholars may lead them to shy away from journals dominated by the presumed greater average liberalism of sociological scholars. JELS, CELS, SELS, and ELS, by not being associated with a discipline, can promote participation by all disciplines, thereby encouraging interchange among them in ELS outlets. ELS helps get these scholars in the same room. It, of course, cannot control the degree to which they interact with one another.

A concern about no mandatory disciplinary loyalty is the possible absence of scholarly rigor that discipline-specific training provides. Scholarly rigor can take the form of requiring that a theory be clearly articulated before empirical tests are designed or results are reported. ${ }^{76}$ One sometimes hears descriptive empirical work dismissed with the comment that, "I was taught that one had to have a theoretical basis for a study before pursuing data." The blog pundit quoted above seems to be picking up on the same theme by stressing the need for an analytical framework. $^{77}$ In some fields that contribute to ELS, particularly experimental psychology or experimental economics, it is hard to imagine designing an experiment without an underlying theory whether or not the project has a legal component.

75. Suchman \& Mertz, supra note 8, at 569-70.

76. E.g., M. Hashem Pesaran \& Ron Smith, The Role of Theory in Econometrics, $67 \mathrm{~J}$. ECONOMETRICS 61, 63 (1995) (describing traditional strategy in which "the theorist provided the model and the econometrician estimated and tested it").

77. See supra note 41 and accompanying text. 
Other ELS scholarship is more data driven; studies may be done largely because data are available, but no apology is needed for doing so. Many important data sets are created to facilitate empirical studies by researchers by saving them the time and cost of gathering high-quality data. This is not peculiar to law. Medical researchers often conduct studies because of the availability of data such as those in the National Health and Nutrition Examination Survey ${ }^{78}$ and in the National Health Interview Survey. ${ }^{79}$ Economic researchers often do studies because of the availability of data such as those in the Consumer Expenditure Survey ${ }^{80}$ and the Panel Study of Income Dynamics. ${ }^{81}$ Law-specific data sets include the studies of civil justice by the Bureau of Justice Statistics ${ }^{82}$ and the important data about federal courts generated by the Administrative Office of the United States Courts. ${ }^{83}$

Of course data-driven studies should set out with some reasonable research question in mind. But conducting a study because data are available is not troublesome; it demonstrates the foresight of those who created the data set.

Stepping back from the details of the data and theory in studies, little doubt exists that law schools play a prominent role in interdisciplinary studies. It is not uncommon for leading law schools to have many faculty members with $\mathrm{PhD}$ degrees in other disciplines. One is no longer surprised if a law school faculty member holds a $\mathrm{PhD}$ in psychology, economics, or political science. I suspect that it would still be surprising for a faculty member in one of those departments to hold an advanced degree in another discipline.

Part of this asymmetry likely relates to salary structure; people with additional training may tend to prefer the department that can pay the highest salary. But part of the asymmetry is likely a function of leading law schools' relative openness to other disciplinary training. For example, of JELS authors through the September 2010 issue, the overwhelming majority of those with multiple advanced degrees are located in law

78. National Health and Nutrition Examination Survey, CTRS. DISEASE CONTROL \& PREVENTION, http://www.cdc.gov/nchs/nhanes.htm (last updated July 19, 2011).

79. National Health Interview Survey, CTRS. DiseASE CONTROL \& PREVENTION, http://www. cdc.gov/nchs/nhis.htm (last updated June 22, 2011).

80. Consumer Expenditure Survey, BUREAU LAB. STAT., http://www.bls.gov/cex/ (last visited July 25, 2011).

81. The Panel Study of Income Dynamics - PSID - Is the Longest Running Longitudinal Household Survey in the World, PSID: INST. FOR SOC. RES., http://psidonline.isr.umich.edu/ (last visited July 25, 2011).

82. E.g., Theodore Eisenberg et al., The Decision to Award Punitive Damages: An Empirical Study, 2 J. Legal AnAlysis 577, 578 (2010); Theodore Eisenberg et al., Juries, Judges, and Punitive Damages: Empirical Analyses Using the Civil Justice Survey of State Courts 1992, 1996, and 2001 Data, 3 J. EMPIRICAL LEgal STUD. 263, 263-66 (2006); Theodore Eisenberg et al., The Predictability of Punitive Damages, 26 J. LEGAL STUD. 623, 632-33 (1997).

83. E.g., Kevin M. Clermont \& Theodore Eisenberg, Xenophilia or Xenophobia in U.S. Courts? Before and After 9/11, 4 J. EMPIRICAL LEGAL STUD. 441, 452-53 (2007); Federal Court Cases: Integrated Data Base, 1970-2000, ICPSR: INTER-UnIV. CONSORTIUM POL. \& SOC. Res., http://www.icpsr. umich.edu/icpsrweb/ICPSR/studies/08429 (last visited July 25, 2011). 
schools. Law-related interdisciplinary studies are, by this measure, dominated by law school faculty. This helps explain why a law-schoolcentered journal, JELS, fares well in impact in a law-based database relative to other law-related journals.

E. Impact Beyond the Academy: Interest of Courts, Policy Makers, and Media

Some bloggers have bemoaned the irrelevance of ELS, calling it "increasingly mysterious and disconnected from the central normative and conceptual questions of legal scholarship and legal education," critique that should be differentiated from concerns about law and economics sometimes being too technical resulting in a concern about "the fetishization of technical skills at least partially for the proliferation of empirical legal scholarship that is irrelevant to the law." ${ }^{95}$ The irrelevance concern seems to me particularly unfounded in the case of ELS. Widespread interest exists inside and outside the orbit of legal professionals in how the legal system operates, but the legal academy has done a poor job of studying and communicating core characteristics of the system's operations. This deficiency leads to at least two classes of troublesome consequences.

\section{The Knowledge Shortfall Leaves All Stakeholders with Inadequate Information}

First, the knowledge shortfall leaves everyone-litigants, policy makers, the media, and the legal profession - without basic knowledge of how the legal system is actually functioning. Only through massive efforts by organizations such as the National Center for State Courts does the United States have elementary unbiased estimates of the outcomes of state court trials. ${ }^{86}$ Systematic knowledge of settlement rate, the modal outcome in civil litigation, exists largely in relatively few studies isolated by time or locale, and even less information is available about the terms of settlements. ${ }^{87}$

Reaction to one empirical study, in the Israeli context, illustrates the thirst for systematic information about the legal system's operation. I have been collaborating with colleagues at Tel Aviv University School of Law, Talia Fisher, and Issi Rosen-Zvi, to produce an empirical study of

84. Leiter, supra note 41

85. Josh Wright, ELS, Technical Fetishization vs. Legal Relevance, and a Partial Defense of the Perfectly Proportional Mediocrity of Legal Empiricists, TRUTH ON MKT. (July 8, 2010, 9:14 AM), http:// truthonthemarket.com/2010/07/08/els-technical-fetishization-vs-legal-relevance-and-a-partial-defenseof-the-perfectly-proportional-mediocrity-of-legal-empiricists/.

86. Information \& Resources, NCSC: NAT'L CTR. FOR CTS., http://www.ncsc.org/Informationand-Resources.aspx (last visited July 25, 2011).

87. Eisenberg \& Lanvers, supra note 63, at 112. 
Israeli Supreme Court (ISC) case outcomes. ${ }^{88}$ Our mostly descriptive study includes findings about the rate at which the ISC grants review of cases, the difference in reversal rates in cases reviewed under mandatory jurisdiction compared to discretionary jurisdiction, the rate at which individuals and corporations succeed, and the rate at which the government succeeds as a litigant. ${ }^{89}$ We make no earthshaking policy recommendations and are largely content to describe the patterns of cases and dispositions by the ISC. One would expect such a project would be of interest to legal academics, although I believe it should be of interest to practicing lawyers. For example, it should be of interest to criminal lawyers to know that their chances of having the ISC overturn a district court affirmance of a conviction are very low.

What is surprising is the study's interest to the media. The findings have been reported as a lead story in The Marker ${ }^{90}$ a leading Israeli financial newspaper, in Haaretz, ${ }^{91}$ a leading Israeli newspaper, and on Israeli television and radio news. I think the media coverage, which matches similar coverage of empirical legal work in the United States, ${ }^{92}$ shows that knowledgeable reporters, policy makers, and society have a strong demand for reliable information about the legal system. In the United States, interested readers about the legal system are fed predominantly a diet of social science propaganda by self-interested groups. ${ }^{93}$

88. Theodore Eisenberg et al., Israel's Supreme Court Appellate Jurisdiction: An Empirical Study, 96 CoRnell L. ReV. 693 (2011). Previous empirical studies conducted of the ISC include the following: Gad BARzilai et AL., The IsRaeli Supreme Court AND the IsRaeli Public (1994); Yoav Dotan, Do the "Haves" Still Come Out Ahead? Resource Inequalities in Ideological Courts: The Case of the Israeli High Court of Justice, 33 LAW \& SoC'Y REv. 1059 (1999); Yoav Dotan \& Menachem Hofnung, Interest Groups in the Israeli High Court of Justice: Measuring Success in Litigation and in Out-of-Court Settlements, 23 LAW \& POL'Y 1 (2001); Meron Gross \& Yoram Shachar, How Are Supreme Court Panels Selected-A Quantitative Analysis, 29 Hebrew U. L. ReV. 567 (1999) (in Hebrew); Menachem Hofnung \& Keren Weinshall Margel, Judicial Setbacks, Material Gains: Terror Litigation at the Israeli High Court of Justice, 7 J. EMPIRICAL LEGAL STUD. 664 (2010); Eli Salzberger, Acting Justices in the Supreme Court and Judicial Independence-Theoretical Analysis and Empirical Findings, 19 BAR-ILAN L. ReV. 541 (2003) (in Hebrew); Yoram Shacher et al., 100 Leading Precedents - A Quantitative Analysis, 7 HAIFA U. L. REV. 243 (2003) (in Hebrew); Yoram Shachar et al., Anatomy of Discourse and Dissent in the Supreme Court-Quantitative Analyses, 20 TEL AVIV U. L. Rev. 749 (1997) (in Hebrew); Yoram Shachar et al., Reference Patterns of the Supreme Court-A Quantitative Analysis, 27 HeBrew U. L. REV. 119 (1996) (in Hebrew).

89. See Eisenberg et al., supra note 88.

90. Ido Baum, The Chances of Defeating the State in an Appeal to the ISC Are Slim, MARKER, June 15, 2010 (in Hebrew).

91. Ido Baum, Unequal Before the Law, HAARETZ.COM (June 16, 2010, 3:29 AM), http://www. haaretz.com/print-edition/business/unequal-before-the-law-1.296446.

92. E.g., Nathan Koppel, Empirical Holy War: Cornell Law Prof Takes on Chamber of Commerce, WALL ST. J. L. BLOG (Sept. 24, 2009, 4:51 PM), http://blogs.wsj.com/law/2009/09/24/empiricalholy-war-cornell-law-prof-takes-on-us-chamber-of-commerce/.

93. William Haltom \& Michael McCann, Distorting the Law: Politics, Media, and THE LITIGATION CRISIS 147-49 (2004). 


\section{Knowledge Shortfall Allows Self-Interested Parties to Promote Biased Data}

Second, the shortfall in reliable information about the legal system allows self-interested parties to fill the information gap with biased studies marketed as neutral social science. One illustration has been the empirical study of punitive damages. For many years, groups like the American Tort Reform Association (ATRA) and the U.S. Chamber of Commerce (Chamber) have spread questionable information about punitive damages and other aspects of the U.S. legal system. ${ }^{94}$ The Chamber, a private lobbying organization despite its official-sounding name, annually criticizes state judiciaries on the basis of a biased, flawed survey it sponsors ${ }^{95}$ and circulates. The Chamber uses its questionable information to promote tort reform. ${ }^{96}$ The Chamber's surveys have treated states that do not allow punitive damages as having them, states that did have punitive damages as not having them, and produced utterly implausible rankings of states' treatment of punitive damages. ${ }^{97}$ The Chamber's surveys were so erroneous in their treatment of punitive damages that it is not surprising that the punitive damages issue was dropped in the Chamber's latest survey (as of this writing), despite its respondents' interest in punitive damages. ${ }^{98}$ The Chamber may wish to avoid any questions that allow its flawed methodology to be exposed and instead rely on pure opinion. ATRA claims that, "[r]eform is urgently needed to restore balance, fairness, and predictability to punitive damages law." 99 ATRA cites none of the credible information about patterns of punitive damages awards. Swiss Re, an international reinsurer, has echoed the unsupported Chamber and ATRA claims. ${ }^{100}$

Empirical data have allowed exposure of the shoddy empirical claims made by the Chamber and ATRA. In contrast to their claims, data made available by the National Center for State Courts have led to general acknowledgment that the "mass of punitive damages awards have been reasonably sober, modest in size, and without significant increases over time." ${ }^{101}$ The U.S. Supreme Court has recognized these em-

94. Theodore Eisenberg, U.S. Chamber of Commerce Liability Survey: Inaccurate, Unfair, and Bad for Business, 6 J. EMPIRICAL LEGAL STUD. 969, 969-70 (2009).

95. Id.

96. Id. at $1001-02$.

97. Id. at $980-83$.

98. Harris Interactive, 2010 U.S. Chamber of Commerce State Liability Systems RANKING STUDY 88 (2010), http://courts.delaware.gov/Courts/Superior/pdf/harris_2010.pdf

99. Punitive Damages Reform, ATRA: AM. TORT REFORM Ass'N, http://www.atra.org/show/73 43 (last visited July 25, 2011).

100. Swiss Re, The Globalisation of Collective Redress: Consequences for the INSURANCE INDUSTRY 2 (2009), http://media.swissre.com/documents/Globalisation_of_Collective_ Redress_en.pdf ("Well-publicized cases involving significant punitive damages have led to the commonly-held view that awards are becoming increasingly extreme.").

101. Theodore Eisenberg et al., Variability in Punitive Damages: Empirically Assessing Exxon Shipping Co. v. Baker, 166 J. Institutional \& THEORETICAL ECON. (JITE) 5, 5-6 (2010). 
pirical facts. ${ }^{102}$ Neither the Chamber nor ATRA seeks to seriously defend their claims. Repeating their message, regardless of its accuracy, appears to be their preferred approach.

\section{CONCLUSION}

Whether one regards ELS as a natural successor to legal realism, as a loosely connected set of scholars across disciplines, or as simply incorporating social science methodology into the study of the legal system, it has grown remarkably quickly. I believe this is because it holds great promise in several areas. ELS can provide systematic knowledge of an important aspect of society-the legal system-similar to knowledge available about other central features of society, such as the economy, crime, and health care. These other features have highly developed datagathering systems in place that dwarf the available information about legal systems.

ELS can provide a common intellectual environment in which scholars from diverse disciplines communicate and collaborate. Conversations at recent CELS conferences note that one desirable CELS characteristic is that scholars interested in the same substantive area (for example, criminal law and crime) can attend sessions and interact with scholars who study an area from multiple social science perspectives. ${ }^{103}$ This would be less likely to occur at single discipline conferences. No need exists to decide whether economics, sociology, political science, or psychology has the most persuasive or accurate view of the world. Each can make its own contribution without the turf wars generated by disciplines operating in isolation from one another.

ELS also offers the opportunity for international collaboration and communication about legal systems, thus offering an added dimension to comparative law. Legal systems share many features; case filings, adjudicative outcomes in courts of first instance, settlement rates, appeals, appellate outcomes, alternative dispute resolution features, and more. Although data about these features must be interpreted in light of a jurisdiction's distinct features, comparisons across jurisdictions and countries can be useful. Simple knowledge of quantitative characteristics of other countries' legal systems can promote interaction.

ELS also helps counter the perception that elite legal scholarship is increasingly irrelevant to the education of lawyers and to the legal profession. Accurate description and solid analysis of the legal system's operation should be relevant to all stakeholders in the legal system. Whether exposing the social scientific flaws of the Chamber, ${ }^{104}$ presenting

102. Exxon Shipping Co. v. Baker, 554 U.S. 471, 497-99 (2008).

103. See source cited supra note 32.

104. See, e.g., Eisenberg, supra note 94 . 
evidence of the perceived advantage repeat players have in arbitration, ${ }^{105}$ documenting the success rate of employment discrimination plaintiffs, ${ }^{106}$ showing the surprisingly favorable treatment of women in developed countries' inheritance laws, ${ }^{107}$ or showing the in-group biases of Arab and Jewish Israeli judges, ${ }^{108}$ ELS can contribute to a better description and deeper understanding of the legal system and ultimately to its fairness and efficiency through promotion of legal rules that better reflect reality.

But ELS growth likely has at least one important limit that will be difficult to overcome-most law professors and law students are not attracted to quantitative or qualitative empirical analysis. I suspect that course enrollments in ELS-related courses will remain modest, that law school graduates entering academia and the profession will have had little opportunity for ELS training, and that the path of least resistance for most will not involve ELS scholarship.

105. Alexander J.S. Colvin, An Empirical Study of Employment Arbitration: Case Outcomes and Processes, 8 J. EMPIRICAL Legal STUD. 1, 11-16 (2011).

106. Laura Beth Nielsen et al., Individual Justice or Collective Legal Mobilization? Employment Discrimination Litigation in the Post Civil Rights United States, 7 J. EMPIRICAL Legal STUD. 175, 17577 (2010)

107. Daphna Hacker, The Gendered Dimensions of Inheritance: Empirical Food for Legal Thought, 7 J. EMPIRICAL LEGAL STUD. 322, 322-24 (2010).

108. Oren Gazal-Ayal \& Raanan Sulitzeanu-Kenan, Let My People Go: Ethnic In-Group Bias in Judicial Decisions-Evidence from a Randomized Natural Experiment, 7 J. EMPIRICAL LEGAL STUD. 403, 403-05 (2010). 